\title{
PERANCANGAN APLIKASI PENGENAL ALAT MUSIK TRADISIONAL "GANDARA" MENGGUNAKAN MULTIPOINT MOUSE SDK
}

Arena Bayu Chandra Permana, Kodrat Iman Satoto, Kurniawan Teguh Martono

Program Studi Sistem Komputer, Fakultas Teknik, Universitas Diponegoro

arena_bayu@yahoo.com

\begin{abstract}
Young men nowadays have few interest with traditional art, including many kinds of Indonesia musical instruments. Compared with that traditional art, people are more familiar with multimedia application in computer devices. Based on those things, there is an idea to create a computer application to make famous Indonesia musical instruments by giving explanation and make a simulation.

The application's name is "Gandara", a word from sanskrit language that means notes collection. "Gandara" uses MultiPoint Mouse SDK that makes the application to be able played by multiple users. The application is developed using Multimedia Development Life Cycle (MDLC) that consist of concept, design, material collecting, assembly, testing and distribution.

"Gandara" users can learn both of gamelan and angklung by reading the explanation or playing the simulation. With this applicaton, users don't need to face gamelan and angklung directly when they want to exercise. All of "Gandara" functions can work well when tested with black-box method and got positif results when tested by users.
\end{abstract}

Keyterms: Application, Multimedia, MultiPoint Mouse SDK, MDLC, Gamelan, Angklung, Gandara.

\section{Pendahuluan}

Sisi lain perkembangan teknologi mau tidak mau menggerus nilai dan budaya tradisional yang ada di Indonesia. Salah satunya adalah alat musik daerah yang sangat beragam jenisnya. Menurut situs berita online Radar Karawang, generasi muda sekarang ini memiliki minat yang kurang terhadap kesenian tradisional

Dibanding hiburan tradisional tersebut, masyarakat era sekarang ternyata lebih akrab dengan fitur multimedia yang ada di perangkat komputer. Menurut Vaughan (2001), fitur multimedia di komputer yang menggabungkan teks, animasi, gambar, suara dan video dianggap lebih praktis dan menyenangkan.

Berdasarkan latar belakang di atas muncul ide untuk merancang sebuah aplikasi komputer yang dapat mengenalkan kembali alat musik tradisional Indonesia lewat penjelasan dan simulasi. Aplikasi ini diharapkan tidak hanya menjawab permasalahan di atas namun juga dapat menghibur dan digemari masyarakat. Oleh karena itu aplikasi ini akan menggunakan teknologi MultiPoint Mouse SDK yang telah dikembangkan oleh Microsoft sehingga memungkinkan pengguna lebih dari satu orang secara bersamaan (multiuser).

Aplikasi komputer pengenal alat musik daerah ini bernama "Gandara" yang berarti kumpulan nada dalam bahasa sansekerta. Cara kerjanya yaitu masing-masing pengguna akan bekerja sama dalam memainkan beberapa alat musik tradisional dengan menggunakan mouse. "Gandara" membutuhkan kerjasama yang baik dari setiap pengguna agar mendapatkan nada yang indah. Selain itu "Gandara" juga berisi penjelasan mengenai pengetahuan umum alat musik tradisional yang ditampilkan sehingga meningkatkan pengetahuan pengguna.

Tugas akhir ini bertujuan untuk :

1. Merancang sebuah aplikasi yang berisi penjelasan dan simulasi memainkan alat musik tradisional Indonesia.

2. Mengimplementasikan MultiPoint Mouse SDK ke dalam sebuah aplikasi.

Untuk menghindari pembahasan yang meluas, maka dalam tugas akhir ini ditetapkan batasan-batasan masalah sebagai berikut:

1. Aplikasi dirancang menggunakan Microsoft Visual Studio 2010 dengan bahasa pemrograman C\#.

2. Aplikasi dijalankan pada sistem operasi Microsoft Windows 7 dan Microsoft Windows 8.

3. Alat musik tradisional yang ditampilkan di aplikasi ini berjumlah terbatas.

4. Aplikasi ini bersifat purwarupa.

5. Penelitian ini hanya bertujuan untuk merancang aplikasi "Gandara" dan tidak membahas dampak penggunaan aplikasi tersebut di masyarakat.

6. Aplikasi "Gandara" yang dibuat dalam penelitian ini hanya bersifat simulasi dan tidak mencontoh keseluruhan sifat alat musik tradisional.

\section{DASAR TEORI}

\subsection{Perangkat Lunak Aplikasi}

Menurut Mathkour (2009), Perangkat lunak aplikasi adalah sekumpulan program yang dirancang untuk menyelesaikan tugas spesifik 
dengan sebuah antarmuka yang sederhana. Perangkat lunak aplikasi sendiri merupakan turunan dari perangkat lunak komputer yang dibagi dua, yaitu perangkat lunak sistem dan perangkat lunak aplikasi itu sendiri.

Fungsi Perangkat lunak aplikasi sendiri dapat mencakup banyak hal termasuk bisnis, pendidikan, komunikasi, multimedia hingga hiburan. Secara umum aplikasi komputer dapat dibagi menjadi dua, yaitu generalized package dan customized package.

a. Generalized Package

Jenis ini merupakan perangkat lunak aplikasi yang dikembangkan untuk semua kalangan secara umum meskipun fungsinya juga spesifik tiap aplikasi.

b. Customized Package

Perangkat lunak aplikasi jenis ini dirancang secara khusus untuk memenuhi persyaratan spesifik dari suatu organisasi atau institusi.

\subsection{Multimedia}

Multimedia merupakan penggabungan dari elemen-elemen multimedia yang disampaikan dengan komputer atau dimanipulasi secara digital dan dapat disampaikan atau dikontrol secara interaktif (Vaughan, 2001).

Dengan penggunaan multimedia, penyampaian informasi akan menjadi lebih menarik dan mempermudah pengguna dalam mendapatkan informasi tersebut. Dari pendapat Hofstetter (2004), menyebutkan bahwa seseorang hanya akan mendapatkan $20 \%$ dari apa yang mereka lihat dan 30\% dari yang mereka dengar. Sedangkan melalui multimedia akan mendapatkan $50 \%$ dari apa yang mereka lihat dan dengar, sampai $80 \%$ dari apa yang mereka lihat, dengar dan berinteraksi dengan pada waktu yang sama.

Menurut Hofstetter (2004), elemen-elemen yang terdapat pada multimedia secara umum terbagi atas lima jenis, yaitu:

a. Teks

Teks merupakan elemen multimedia yang menjadi dasar untuk menyampaikan informasi, karena teks adalah jenis data yang paling sederhana dan membutuhkan tempat penyimpanan yang paling kecil. Teks merupakan cara yang paling efektif dalam mengemukakan ide-ide kepada pengguna, sehingga penyampaian informasi akan lebih mudah dimengerti oleh masyarakat.

b. Grafik

Sangat bermanfaat untuk mengilustrasi informasi yang akan disampaikan terutama informasi yang tidak dapat dijelaskan dengan katakata.

\section{c. Audio}

Multimedia tidak akan lengkap jika tanpa audio atau suara. Audio bisa berupa percakapan, musik atau efek suara.

d. Video
Video menyediakan sumber yang kaya dan hidup untuk aplikasi multimedia. Dengan video dapat menerangkan hal-hal yang sulit digambarkan lewat kata-kata atau gambar diam dan dapat menggambarkan emosi dan psikologi manusia secara lebih jelas.

e. Animasi

Animasi adalah simulasi gerakan yang dihasilkan dengan menayangkan rentetan frame ke layer. Frame adalah satu gambar tunggal pada rentetan gambar yang membentuk animasi.

\subsection{Windows MultiPoint Mouse SDK}

Microsoft Windows, telah mendukung teknologi mouse yang lebih mutakhir dan simultan. Tapi karena sistem operasi Windows hanya menyediakan sebuah penunjuk layar (pointer), maka penggunaan lebih dari satu perangkat dalam waktu yang sama dapat menimbulkan kebingungan pada pengguna. MultiPoint Mouse SDK sering digunakan dalam permainan atau aplikasi yang membutuhkan banyak pengguna sekaligus yang memang dirancang untuk menerima masukan secara banyak secara bersamaan. Skema perangkat komputer yang sudah mendukung MultiPoint Mouse SDK dapat diamati pada Gambar 2.1 (Microsoft Technical Document, 2010).

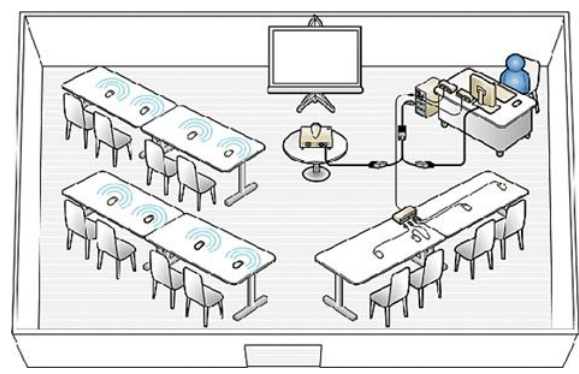

Gambar 2.1 Gambaran MultiPoint Mouse

Perkembangan berikutnya Microsoft terus mengembangkan aplikasi ini sehingga sistem operasi terbaru memungkinkan penggunaan hingga 25 pointer secara bersamaan. Teknologi ini pun tidak melulu untuk tampilan yang membosankan namun juga sudah dipadukan dengan perkembangan grafis dan suara yang menarik.

Microsoft juga merekomendasikan perangkat keras ketika pengembang berniat menggunakan SDK ini, yaitu:

1. Sebuah komputer, uji coba menggunakan pentium 4 berlangsung dengan sukses sehingga dapat digunakan pada komputer berspesifikasi minim.

2. 2 hingga 4 mouse untuk pengujian.

3. USB port.

4. RAM minimal $128 \mathrm{MB}$.

5. RAM video minimal $16 \mathrm{MB}$.

6. Video Card resolusi minimal 800 x 600 dan warna minimal 32-bit sangat disarankan. 


\subsection{Bahasa C\#}

C\# merupakan sebuah bahasa pemrograman yang handal dan fleksibel dengan sebuah sejarah yang menarik. Bahasa pemrograman ini dikembangkan oleh Microsoft Corporation dengan alasan yang bermacam-macam, beberapa secara teknis, beberapa politik dan lainnya marketing (Miles, 2014).

C\# merupakan sebuah bahasa pemrograman yang berorientasi objek sebagai bagian dari inisiatif kerangka .NET Framework. Bahasa pemrograman ini dibuat berbasiskan bahasa $\mathrm{C}++$ yang telah dipengaruhi oleh aspek-aspek lainnya. Bahasa pemrograman ini dikenalkan pertama kali pada tahun 2000 sebagai bahasa pemrograman yang modern dan menjawab kelemahan-kelemahan yang ada pada bahasa pemrograman lainnya.

Menurut Risal (2011), bahasa C\# mempunyai karakteristik sebagai berikut:

\section{Sederhana}

C\# bersifat sederhana, karena bahasa ini didasarkan kepada bahasa $\mathrm{C}$ dan $\mathrm{C}++$. Banyak fungsi yang mirip dengan $\mathrm{C}$ dan $\mathrm{C}++$ atau bahkan Java, pemrogram akan menemukan aspek-aspek yang begitu familiar.

2. Modern

Banyak fitur-fitur yang terdapat pada C\# yang sangat membudahkan pemrogram seperti exception handling, garbage collection, extensible data types, dan code security (keamanan kode/bahasa pemrograman). Dengan adanya fitur-fitur tersebut, menjadikan bahasa $\mathrm{C \#}$ sebagai bahasa pemrograman yang modern.

3. Berorientasi Objek

Kunci dari bahasa pemrograman yang berorientasi objek adalah encapsulation, inheritance dan polymorphism.

4. Handal dan Fleksibel

C\# bisa digunakan untuk membuat berbagai macam aplikasi seperti aplikasi pengolah kata, grafik, spreadsheets, atau bahkan membuat kompiler untuk sebuah bahasa permrograman.

5. Efisien

C\# adalah bahasa pemrograman yang menggunakan jumlah kata-kata yang tidak terlalu banyak. C\# hanya berisi kata-kata yang biasa disebut dengan keywords. Keywords ini digunakan untuk menjelaskan berbagai macam informasi.

6. Modular

Kode C\# ditulis dengan pembagian yang terdiri dari beberapa routines yang disebut sebagai member methods. Kelas-kelas dan metodemetode ini dapat digunakan kembali oleh program atau aplikasi lain.

\subsection{Windows Presentation Foundation (WPF)}

Windows Presentation Foundation (WPF) merupakan sistem presentasi modern buatan Windows dengan tampilan pengguna yang sangat dinamis. WPF juga memungkinkan pemrogram dapat membuat aplikasi berbasis mandiri atau berbasis web (Griffiths, 2005).

Inti dari WPF adalah resolusi yang independen dan mesin rendering yang berbasis vektor untuk memanfaatkan keuntungan dari perangkat grafis modern. WPF juga didukung oleh beberapa fitur pengembangan aplikasi termasuk Extensible Applicaton Markup Language (XAML), kontrol, data binding, layout, grafis 2 dimensi maupun 3 dimensi, animasi, styles, templates, dokumen, media, dan teks. Microsoft .NET

Griffiths (2005) juga mengemukakan bahwa pemisahan dari pengaturan tampilan dan pola aplikasi ini memiliki beberapa keuntungan yaitu:

1. Biaya pengembangan dan perawatan berkurang karena pengaturan khusus tampilan tidak menjadi satu dengan pengaturan khusus pola aplikasi.

2. Pengembangan aplikasi yang lebih efisien karena desainer dapat langsung membuat tampilan aplikasi saat pemrogram juga menulis kode program.

3. Alat dan fitur bantu desain dapat digunakan untuk menerapkan XAML.

\subsection{Metodologi Pengembangan Multimedia}

Metodologi yang digunakan adalah Multimedia Development Life Cycle (MDLC) yang bersumber dari Luther dan sudah dimodifikasi oleh Sutopo. Metodologi pengembangan multimedia tersebut terdiri dari enam tahap, yaitu konsep (concept), desain (design), pengumpulan materi (material collecting), pembuatan (assembly), pengujian (testing), dan distribusi (distribution). Keenam tahap ini tidak harus berurutan dalam prakteknya, tahap-tahap tersebut dapat saling bertukar posisi.

1. Konsep (Concept)

Tahap konsep adalah tahap untuk menentukan tujuan dan siapa pengguna (identifikasi audiensi). Karena tujuan dan pengguna akhir dari program akan mempengaruhi konsep multimedia yang akan dibuat. Selain itu, ini akan menentukan jenis aplikasi dan tujuan aplikasi.

2. Desain (Design)

Desain adalah tahap pembuatan spesifikasi mengenai arsitektur program, gaya, tampilan, dan alur program yang dapat disajikan dalam bentuk bagan alir (flowchart).

3. Pengumpulan Materi (Material Collecting) Pengumpulan materi adalah tahap pengumpulan bahan yang sesuai dengan kebutuhan pemuatan aplikasi. Bahan-bahan tersebut antara lain materi yang akan dibahas, foto, animasi dan video.

4. Pembuatan (Assembly) 
Pada tahap ini dilakukan pembuatan semua objek atau bahan multimedia. Pembuatan aplikasi didasarkan pada tahap perancangan. Untuk pembuatan aplikasi pada tahap ini biasanya menggunakan perangkat lunak seperti Macromedia Director, Macromedia Flash.

5. Pengujian (Testing)

Tahap pengujian dilakukan setelah menyelesaikan tahap pembuatan dengan menjalankan aplikasi/program dan melihat hasilnya apakah ada kesalahan atau tidak.

6. Distribusi (Distribution)

Pada tahap ini, aplikasi akan disimpan dalam suatu media penyimpanan. Jika media penyimpanan tidak cukup untuk menampung aplikasinya, maka kompresi terhadap aplikasi tersebut akan dilakukan. Tahap ini juga dapat disebut tahap evaluasi untuk pengembangan produk yang sudah jadi supaya menjadi lebih baik.

\section{Perancangan Sistem}

\subsection{Konsep}

Aplikasi yang dibuat dalam penelitian tugas akhir ini bertujuan untuk membuat simulasi dan mengenalkan kembali musik tradisional Indonesia kepada masyarakat. Obyek penelitian ini memiliki kategori pada jenjang sekolah dasar hingga perguruan tinggi. Pada rentang usia tersebut, seseorang sedang dalam masa aktif belajar sehingga diharapkan tujuan untuk mengenalkan kembali alat musik tradisional Indonesia ini dapat tersampaikan dengan baik.

Untuk itu dibutuhkan suatu konsep aplikasi yang tepat agar obyek penelitian dapat tertarik menggunakan aplikasi ini.Selain itu aplikasi harus berisi konten-konten yang tidak hanya teoritis tetapi juga teknis tentang alat musik tradisional guna hasil yang lebih optimal.

Sebagai acuan pembuatan aplikasi pada tahap berikutnya maka perlu disusun suatu skenario agar aplikasi yang dibuat sesuai dengan apa yang diharapkan. Skenario dari aplikasi "Gandara" ini yaitu sebagai berikut:

1. Aplikasi "Gandara" terdiri dari 8 buah halaman yaitu halaman awal, halaman pointer gamelan, halaman pointer angklung, halaman penjelasan gamelan, halaman penjelasan angklung, halaman utama gamelan dan halaman utama angklung.

2. Pada halaman awal pengguna dapat memilih satu dari dua kelompok alat musik pada aplikasi "Gandara" ini yaitu gamelan dan angklung.

3. Pengguna dengan batasan lima orang dapat memainkan alat musik gamelan atau angklung secara bersama-sama dan masing-masing orang hanya dapat memainkan 1 alat musik.
4. Pengguna dapat memilih alat musik yang dikehendakinya dan dapat melakukan reset ketika terdapat kesalahan.

5. Hanya pengguna dengan mouse id $=0$ atau pada awal aplikasi mendapat pointer dengan teks 'Pimpinan Gandara' yang dapat mengoperasikan tombol-tombol navigasi pada aplikasi.

6. Aplikasi yang menggunakan MultiPoint Mouse SDK tidak dapat menggunakan tombol close pada jendela biasa sehingga untuk keluar dari aplikasi dapat menggunakan tombol Escape pada keyboard dan untuk melakukan restart aplikasi dapat menggunakan tombol Tab.

\subsection{Desain}

Dalam tahap desain ini dibagi menjadi dua, yaitu merancang pembuatan alur aplikasi melalui diagram alir dan merancang desain tampilan aplikasi.

Perancangan alur aplikasi dibuat menggunakan diagram alir setiap halaman yang ada pada aplikasi. Diagram alir halaman awal aplikasi ditunjukkan oleh Gambar 3.1.

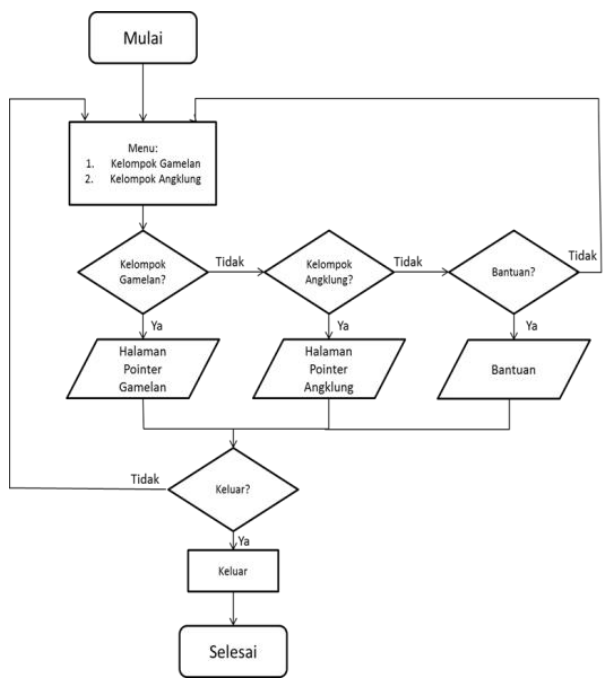

Gambar 3.1 Diagram Alir Halaman Awal

Diagram alir halaman memilih pointer ditunjukkan oleh Gambar 3.2.

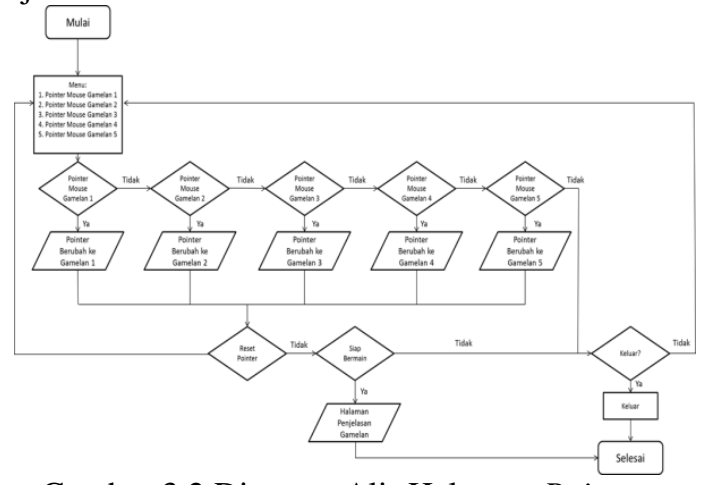

Gambar 3.2 Diagram Alir Halaman Pointer

Diagram alir halaman penjelasan ditunjukkan oleh Gambar 3.3. 


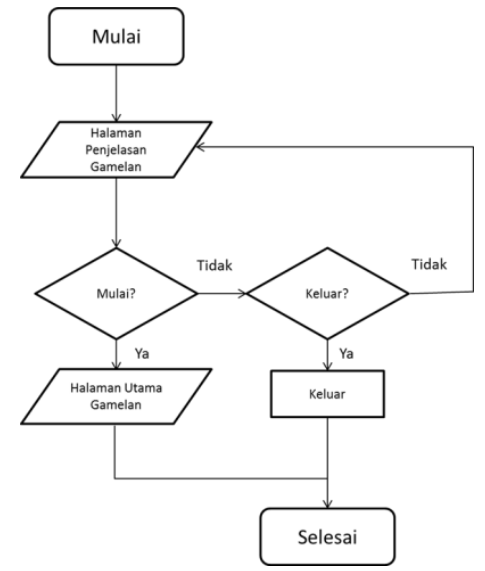

Gambar 3.3 Diagram Alir Halaman Penjelasan

Diagram alir halaman utama ditunjukkan oleh Gambar 3.4.

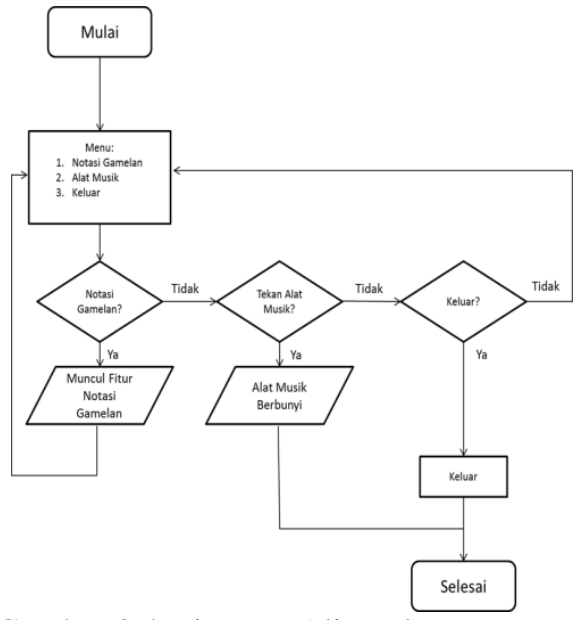

Gambar 3.4 Diagram Alir Halaman Utama

Berikutnya adalah tahap perancangan tampilan aplikasi. Rancangan halaman awal aplikasi ditunjukkan oleh Gambar 3.5.

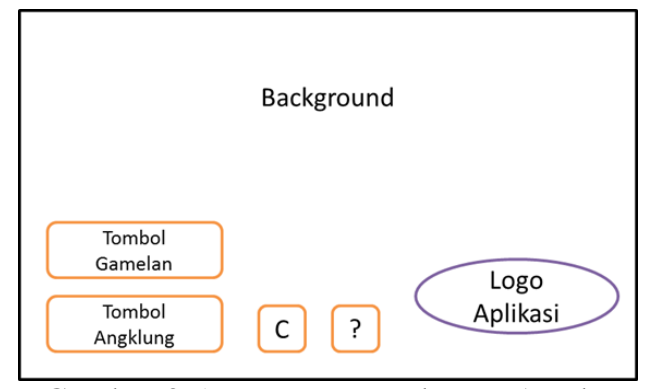

Gambar 3.5 Rancangan Halaman Awal

Rancangan halaman memlih pointer aplikasi ditunjukkan oleh Gambar 3.6.

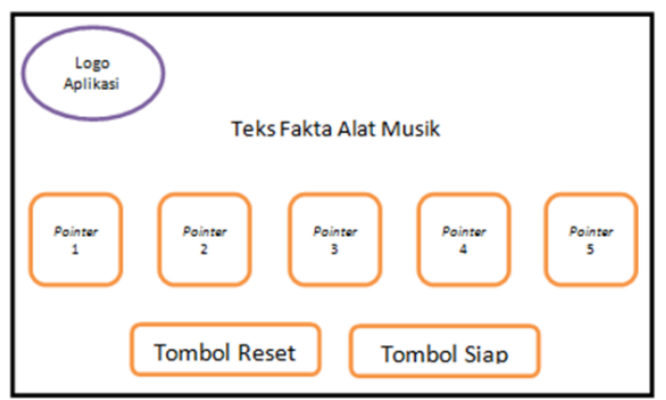

Gambar 3.6 Rancangan Halaman Pointer

Rancangan halaman penjelasan aplikasi ditunjukkan oleh Gambar 3.7.

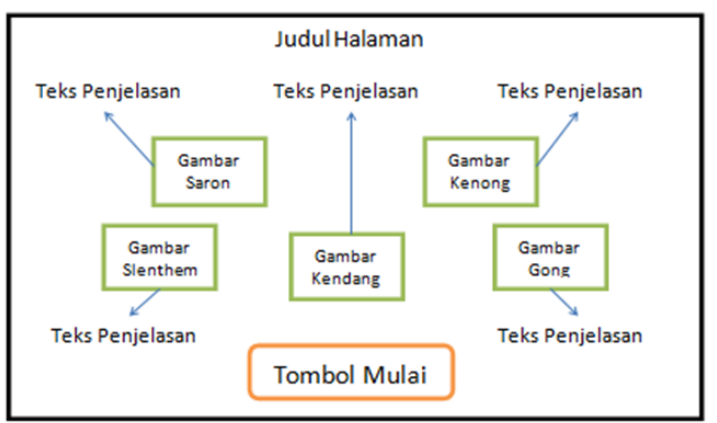

Gambar 3.7 Rancangan Halaman Penjelasan

Rancangan halaman utama aplikasi ditunjukkan oleh Gambar 3.8.

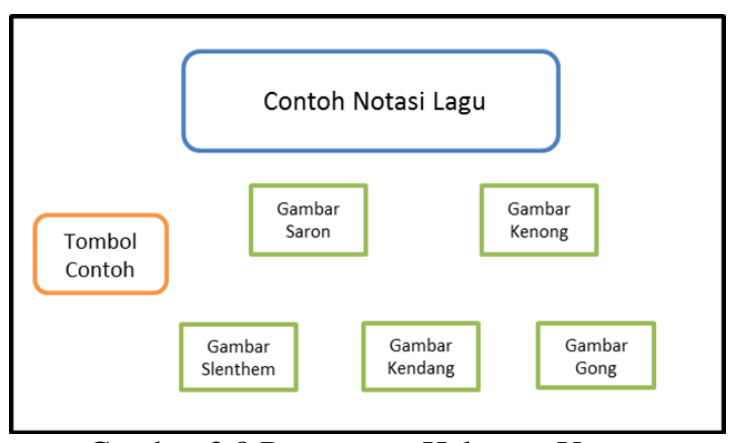

Gambar 3.8 Rancangan Halaman Utama

\section{HaSil dan PEMbahasan}

\subsection{Hasil Perancangan}

Pembuatan aplikasi ini diimplementasi berdasarkan perancangan yang telah dibahas pada Bab III, sehingga dihasilkan suatu permainan yang bekerja sesuai dengan fungsinya. Sedangkan pengujiannya dilakukan dengan metode black-box, serta akan dilakukan juga uji coba permainan secara langsung ke pengguna menggunakan kuesioner. Berikut ini merupakan tampilan aplikasi yang telah dibuat.

1. Halaman Awal Aplikasi

Ketika aplikasi ini pertama dijalankan maka akan masuk pada menu halaman awal aplikasi. Menu halaman awal aplikasi ini ditunjukkan oleh Gambar 4.1 


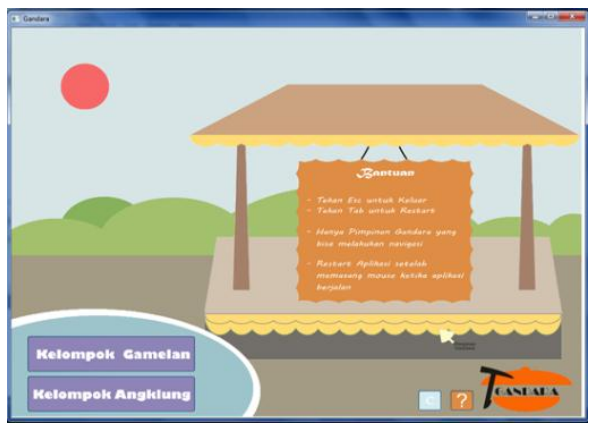

Gambar 4.1 Halaman Awal Aplikasi.

\section{Halaman Memilih Pointer}

Pada halaman memilih pointer ini terdapat lima buah gambar kepala yang nantinya dapat dipilih pengguna sebagai ikon pada pointer masingmasing mouse. Halaman ini dapat dilihat pada Gambar 4.2.

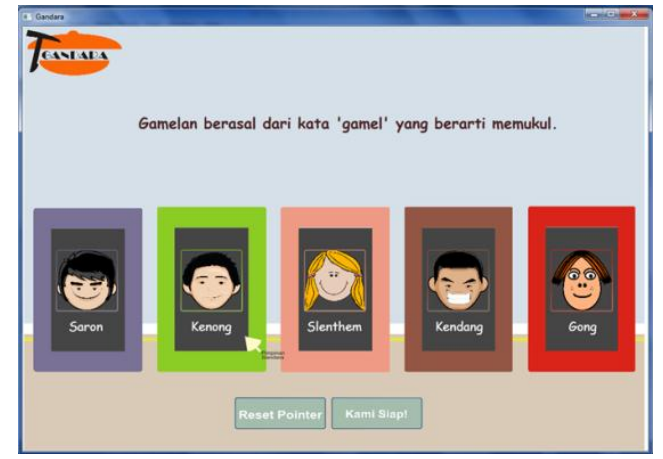

Gambar 4.2 Halaman Memilih Pointer Gamelan

3. Halaman Penjelasan Gamelan

Halaman penjelasan gamelan ini mencoba menjelaskan secara singkat alat-alat musik gamelan yang dapat dimainkan pada aplikasi. Halaman ini dapat dilihat pada Gambar 4.3.

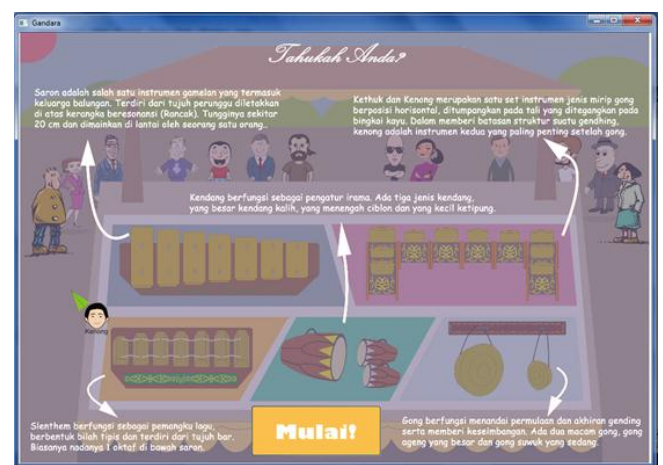

Gambar 4.3 Halaman Penjelasan Gamelan

\section{Halaman Utama Gamelan}

Halaman utama gamelan memiliki gambar latar belakang sebuah panggung dengan lima buah perangkat gamelan di atasnya. Halaman ini dapat dilihat pada Gambar 4.4.

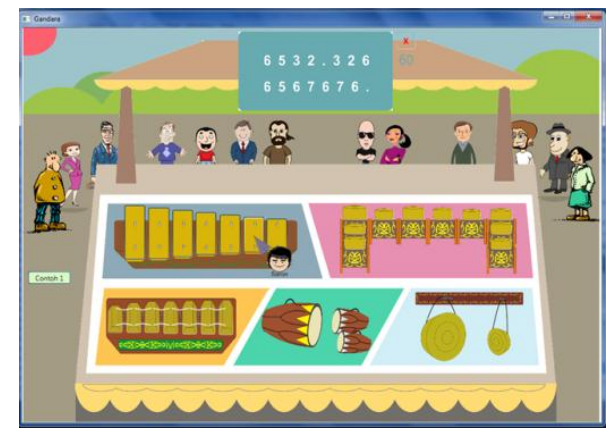

Gambar 4.4 Halaman Utama Gamelan

\subsection{Pengujian dengan Metode Black-box}

Pengujian aplikasi "Gandara" yang telah dibuat dalam penelitian ini dilakukan dengan menggunakan metode black-box. Tahapan pengujian ini berisi rangkaian pengujian tombol dan fungsi yang terdapat dalam aplikasi.

Pengujian ini dilakukan untuk memeriksa fungsi yang terdapat dalam aplikasi, apakah hasilnya sesuai dengan yang diinginkan. Pengujian ini juga dilakukan untuk mengetahui apakah masih terdapat kesalahan dalam aplikasi ataukah masih terdapat kesalahan sehingga secepatnya dapat diberi solusi.

Sebagai contoh pada Tabel 4.1 ditunjukkan contoh pengujian apliaksi menggunakan metode black-box tentang fungsi umum aplikasi.

Tabel 4.1

\begin{tabular}{|l|l|l|c|}
\hline \multicolumn{1}{|c|}{$\begin{array}{c}\text { Nama } \\
\text { Pengujian }\end{array}$} & Bentuk Pengujian & Hasil yang Diharapkan & $\begin{array}{c}\text { Hasil } \\
\text { Pengujian }\end{array}$ \\
\hline $\begin{array}{l}\text { Pengujian Buka } \\
\text { Aplikasi }\end{array}$ & Membuka aplikasi & $\begin{array}{l}\text { Tampil Halaman Awal } \\
\text { Aplikasi }\end{array}$ & Berhasil \\
\hline $\begin{array}{l}\text { Pengujian Restart } \\
\text { Aplikasi }\end{array}$ & $\begin{array}{l}\text { Tekantombol Tab pada } \\
\text { keyboard }\end{array}$ & $\begin{array}{l}\text { Aplikasi akankembalike } \\
\text { halaman awal }\end{array}$ & Berhasil \\
\hline $\begin{array}{l}\text { Pengujian Tutup } \\
\text { Aplikasi }\end{array}$ & $\begin{array}{l}\text { Tekantombol Esc pada } \\
\text { keyboard }\end{array}$ & Aplikasi akantertutup & Berhasil \\
\hline Pengujian Cek Mouse & $\begin{array}{l}\text { Masukkanperangkat } \\
\text { mouse setelah aplikasi } \\
\text { dijalankan }\end{array}$ & $\begin{array}{l}\text { Jumlah pointer akan } \\
\text { bertambah sesuaijumlah } \\
\text { mouse }\end{array}$ & Berhasil \\
\hline
\end{tabular}

\subsection{Pengujian Menggunakan Kuesioner}

Pengujian aplikasi juga dilakukan secara langsung kepada sasaran aplikasi, yaitu pelajar dari jenjang sekolah dasar hingga universitas. Pengujian dilakukan secara obyektif dengan tujuan mengetahui penilaian terhadap aplikasi yang telah dibuat. Pengujian dilakukan pada tanggal 10 hingga 17 Juni 2014 dan dilakukan di beberapa tempat. Proses pengujian ini dilakukan dengan cara meminta sasaran menggunakan aplikasi "Gandara" kemudian dilanjutkan memberi kuesioner mengenai beberapa aspek.

Setiap responden akan diberi 8 sampel pertanyaan dimana setiap pertanyaan terdapat 5 pilihan jawaban, yaitu Sangat Tidak Setuju (STS), Tidak Setuju (TS), Netral (N), Setuju (S), Sangat Setuju (SS). Masing-masing jawaban diberi skor berurutan sampai 5 . 
Hasil dari pengujian ini didapat nilai yang ditunjukkan diagram batang yang dapat dilihat pada oleh Gambar 4.5.

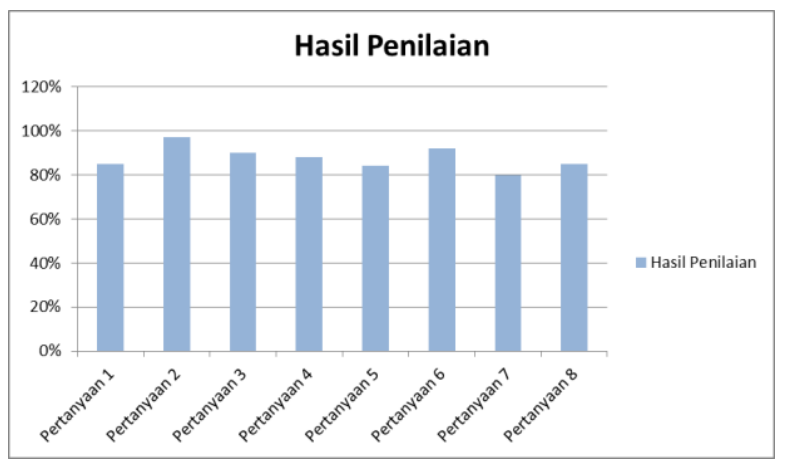

\subsection{Pembahasan}

Hasil pengujian aplikasi menggunakan metode black-box, menunjukkan bahwa permainan sudah berjalan sesuai dengan spesifikasi kebutuhan dan skenario aplikasi. Hal ini ditunjukkan oleh tabel 4.1 hingga tabel 4.8 yang menampilkan hasil uji "Berhasil" pada tiap fungsi aplikasi dan tombol. Secara fungsional, aplikasi ini sudah dapat menghasilkan keluaran yang diharapkan.

Berdasarkan hasil olah data kuesioner didapat skor rata-rata dari semua pertanyaan yaitu sebesar $87.625 \%$. Hasil ini menunjukkan bahwa lebih dari $75 \%$ jawaban kuesioner berisi jawaban positif, atau dapat dikatakan aplikasi yang dibuat sudah berhasil dengan baik. Keseluruhan dari hasil olah data kuisioner dapat disimpulkan bahwa aplikasi yang dibuat telah memenuhi syarat untuk dianggap baik.

Pembuatan aplikasi ini hanya dimaksudkan untuk merancang sebuah aplikasi yang berisi simulasi dan penjelasan tentang alat musik tradisional Indonesia berbasis MultiPoint Mouse SDK, bukan membahas dampak yang terjadi setelah menggunakan aplikasi ini.

Sebenarnya terdapat beberapa aplikasi sejenis yang membawa konsep serupa untuk mengenalkan kembali alat musik tradisional. Namun apliaksi "Gandara" dengan memanfaatkan MultiPoint Mouse SDK memberi inovasi agar apliaksi ini dapat digunakan sekaligus oleh 5 orang pengguna dalam satu buah komputer.

Aplikasi "Gandara" ini tentu juga memiliki kelebihan dan kekurangan. Kelebihan aplikasi "Gandara" ini yaitu:

1. Aplikasi dapat dijalankan pada sistem operasi Windows 7 dan Windows 8.

2. Aplikasi memuat informasi-informasi tambahan yang dimuat secara acak sehingga menambah pengetahuan pengguna tentang alat musik tradisional.

3. Aplikasi mudah digunakan dan berisi penjelasan yang umum namun jelas.

4. Aplikasi dapat dimainkan secara sekaligus oleh 5 orang dengan masing-masing pengguna hanya dapat memainkan 1 jenis alat musik sehingga mirip dengan aslinya.

Adapun kekurangan dari permainan ini yaitu sebagai berikut :

1. Tidak ada kontrol untuk ukuran layar aplikasi.

2. Untuk dapat menggunakan aplikasi ini komputer harus diinstal MultiPoint Mouse SDK terlebih dahulu.

3. Tampilan pointer mouse hanya dipanggil saat awal aplikasi dijalankan atau saat menekan tombol Tab sebagai restart sehingga ketika pengguna menambahkan perangkat mouse baru saat aplikasi berjalan maka lebih baik aplikasi direstart.

\section{KESIMPULAN DAN SARAN}

\subsection{Kesimpulan}

Kesimpulan dari penelitian Tugas Akhir ini diantaranya sebagai berikut.

1. Berdasarkan hasil pengujian aplikasi menggunakan metode Black-box, seluruh fungsi menu yang ada dalam aplikasi telah berhasil sesuai dengan fungsinya.

2. Berdasarkan hasil pengujian aplikasi menggunakan metode Black-box, implementasi MultiPoint Mouse SDK berjalan sesuai dengan yang diharapkan, dengan ditunjukkan oleh aplikasi yang dapat dijalankan dengan 5 buah mouse sekaligus.

3. Berdasarkan hasil olahan data kuisioner menunjukkan bahwa $75 \%$ lebih responden menjawab dengan jawaban positif, artinya lebih dari $75 \%$ responden menjawab dengan jawaban setuju dan sangat setuju. Rata-rata skor untuk seluruh hasil kuesioner adalah $87.625 \%$.

\subsection{Saran}

Saran yang dapat diberikan oleh penulis adalah sebagai berikut.

1. Aplikasi "Gandara" hanya memuat alat musik angklung dan gamelan, diharapkan dapat ditambah dengan alat musik tradisional jenis lain di Indonesia.

2. Tampilan aplikasi "Gandara" hanya diam dan statis, diharapkan dapat ditambah efek animasi sehingga membuat aplikasi ini semakin menarik.

\section{Daftar PUStaka}

Darmawan, E., \& Risal, L., 2011, Pemrograman Berorientasi Objek C\# yang Susah Jadi Mudah, Bandung: Penerbit Informatika.

Griffiths, I., \& Sells, C., 2005, Programming Windows Presentation Foundation, O'Really. 
Hofstetter, F. T., 2011, Multimedia Literacy, 3rd Edition, Irwin/MCGraw-Hill.

Mathkour, H., 2009, Introducing Application Software, King Saud University.

Microsoft, 2010, Getting Started with Windows MultiPoint Mouse SDK 1.5., Microsoft Technical Document.

Miles, R., 2014, Programming "Rubber Duck" Edition, Department of Computer Science University of Hull.

Pramudya, P., 2010, Game Tebak Kartu Multiplayer Microsoft Multipoint SDK, Microsoft Innovation Center Institut Teknologi Bandung.

Vaughan, T., 2011, Multimedia: Making It Work, 5th Edition, Osborne. 